\title{
PENGARUH KONSENTRASI JELLY POWDER TERHADAP KARAKTERISTIK MINUMAN JELI IKAN LELE (Clarias sp.)
}

\author{
Willy Pranata Widjaja \\ Sumartini \\ Rifani \\ Program Studi Teknologi Pangan, Fakultas Teknik, Universitas Pasundan, Jl. Dr.Setiabudi No 93, Bandung,
40153, Indonesia \\ E-mail : willy_tp@unpas.ac.id
}

\begin{abstract}
The motive of research is to find out how to make a jelly drink from catfish. While the purpose of this researchis to determine the effect of jelly powder concentration on the characteristics of catfish jelly drink. The benefits of this research is to provide a reference processing functional beverage made from animal foods, provide product information diversification catfish jelly drinks, manufacturing process of catfish jelly drink and accurate concentrate jelly powder also panelists preferred to make a catfish jelly drink. The research was conducted in two stages; preliminary research and primary research. Preliminary research was involve the removal of the fishy smell, raw materials analysis and determining the ratio of meat catfish and the water that used in the primary research. The method was used in this research is a randomized block design (RBD) with $12 \times 1$ factorial with two replications. Variable concentrations of jelly powder were used to make a catfish jelly drink is

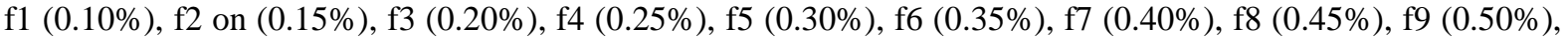
$\mathrm{f} 10(12: 55 \%), \mathrm{f} 11(0.60 \%)$ and $\mathrm{f} 12(0.65 \%)$. Based on the results of research, concentration of jelly powder give significant effect on water content, viscosity, total dissolved solids, color, flavor, texture and appearance of jelly drinks catfish but it is not give significant effect on reducing sugar content and smell. Selected samples of the research are $\mathrm{f} 7$ with the concentration of jelly powder as much as $0.40 \%$ and that catfish jelly drinks contains moisture $80.15 \%$, levels of reducing sugars $1.175 \%$, viscosity $1: 53 \mathrm{dPas}$, total dissolved solids $18.7^{\circ}$ Brix, protein content $3.72 \%$ and levels $1.78 \%$ crude fiber.
\end{abstract}

Keyword: functional food, catfish, jelly powder, catfish jelly drink.

\section{Pendahuluan}

Minuman fungsional adalah salah satu produk pangan fungsional yang saat ini sedang banyak dikembangkan (Winarti, 2010). Makanan atau minuman dikatakan mempunyai sifat fungsional bila mengandung senyawa (zat gizi atau non-gizi) yang dapat mempengaruhi satu atau sejumlah tertentu fungsi fisiologis dalam tubuh, bersifat positif, sehingga dapat memenuhi kriteria fungsional atau menyehatkan (Muchtadi, 2012).

Minuman fungsional modern yang saat ini sedang dikembangkan salah satunya adalah minuman jelly yang bermanfaat bagi saluran pencernaan yang juga mengandung dietary fiber (Hapsari, 2011). Minuman jeli yang saat ini beredar di pasaran umumnya dibuat dari air dan sari buahbuahan atau sayuran serta hanya mengedepankan kandungan serat pangan dan vitamin C. Pada penelitian ini akan dibuat produk diversifikasi minuman jeli yaitu minuman jeli dari ikan lele. Ikan lele dipilih karena merupakan salah satu ikan yang mengandung protein tinggi yang memiliki fungsi fisiologis bagi tubuh, harganya relatif murah serta jumlah produksinya cukup tinggi. Produksi ikan lele di Indonesia dari tahun 2009 sampai Tri Wulan Tiga tahun 2014 mengalami peningkatan sebesar $37.49 \%$ dengan jumlah produksi pada tahun 2014 sebanyak 463.221 ton (Direktorat Jendral Perikanan Budidaya, 2014).

Protein pada ikan lele memiliki beberapa fungsi fungsional yang dapat mendukung proses pembuatan minuman jeli diantaranya penyerapan dan pengikatan air dan mengentalkan (Susanto dan Fahmi, 2012).

Ikan lele selain mengandung gizi protein yang penting seperti protein juga mengandung 10 asam amino esensial yaitu arginine, histidin, isoleusin, leusin, lisin, metionin, fenilalanin, treonin, valin dan triptopan (Astawan, 2008). Menurut Gunawan, dkk (2014), pada bagian kepala dan badan ikan lele baik melalui transesterifikasi enzimatik mengandung asam lemak esensial berupa omega-3 yakni DHA, EPA dan asam lemak omega6 berupa asam linoleat (dari hasil analisis menggunakan alat Gas ChromatographyMassSpectrometry). Asam lemak omega-3 (linolenat) dan asam lemak omega6 (asam linoleat) merupakan asam lemak essensial. Yang diperlukan tubuh, sedangkan tubuh tidak dapat mensisntesisnya. Kedua jenis asam lemak ini dibutuhkan untuk pertumbuhan dan fungsi normal semua jaringan. Kekurangan asam lemak omega-3 menimbulkan gangguan saraf dan penglihatan. Disamping itu kekurangan asam lemak esensial 
menghambat pertumbuhan pada bayi dan anakgangguan pada kulit, ginjal, dan hati (Almatsier, 2009). Hal tersebut yang menjadi alasan dipilihnya ikan lele sebagai sumber bahan baku pembuatan minuman jeli ikan lele.

Minuman jeli ikan lele dibuat dari sari daging ikan lele, bahan pembentuk gel, gula dan bahan tambahan pangan lainnya sesuai dengan kebutuhan dan peraturan yang berlaku. Minuman jeli harus memiliki tekstur kokoh, saat dikonsumsi menggunakan bantuan sedotan mudah hancur, namun bentuk gelnya masih terasa dimulut (Pranajaya, 2007), begitu pula pada minuman jeli

Bahan baku utama yang digunakan dalam penelitian ini adalah ikan lele sangkuriang (Clarias sp.) segar dengan berat kurang lebih $300 \mathrm{~g}$ diperoleh dari daerah Cirata, jelly powder dari Toko Ny. Liem, gula, jeruk lemon dan air. Bahanbahan yang digunakan untuk analisis diantaranya bahan analisis untuk gula pereduksi dengan metode Luff Schrools : larutan Luff Schrools, $\mathrm{H}_{2} \mathrm{SO}_{4} 6 \mathrm{~N}$, $\mathrm{KI}, \mathrm{Na} 2 \mathrm{~S} 2 \mathrm{O} 30.1 \mathrm{~N}$, amylum dan aquadest serta toluen, xylen/xylol, benzen, tetrakloretilen untuk analisis kadar air dengan metode destilasi. Sedangkan bahan-bahan yang digunakan untuk analisis produk terpilih yaitu bahan analisis serat kasar dengan menggunakan metode gravimetri : $\mathrm{H}_{2} \mathrm{SO}_{4} 1.25 \%$, NaOH $3.25 \%$, etanol $96 \%$ dan tanur, segitiga porselen, kawat kasa, kaki tiga, bunsen, labu kjeldahl, alat destilasi, pipet tetes, labu takar, batang pengaduk, erlenmeyer, buret, pipet volumetric, refraktometer dan $\mathrm{pH}$ meter.

\section{Penghilangan Bau Amis}

Penelitian pendahuluan tahap pertama dilakukan untuk menentukan konsentrasi air perasan jeruk lemon untuk menghilangkan bau amis pada daging ikan lele dengan perlakuan perendaman dalam air perasan jeruk lemon dengan konsentrasi air peras adalah: a1 $=0 \%, \mathrm{a} 2=5 \%$, a3 $=10 \%, \mathrm{a} 4=15 \%, \mathrm{a} 5=20 \%$ selama 30 menit. Daging ikan lele yang telah direndam air jeruk lemon kemudian dicuci, ditiriskan dan selanjutnya dibuat menjadi minuman jeli ikan lele. Produk minuman jeli ikan lele kemudian diuji secara organoleptik. Uji organoleptik dilakukan menggunakan uji hedonik atau uji kesukaan dengan parameter warna, aroma, rasa, tekstur dan kenampakan, dilakukan oleh 20 orang panelis semi terlatih. dan Air

Penentuan Perbandingan Daging Ikan Lele

Hasil nilai uji parameter terbaik dari penelitian tahap pertama selanjutnya digunakan untuk penelitian pendahuluan tahap kedua yaitu menentukan perbandingan proporsi daging ikan lele dan air yang digunakan untuk membuat sari daging ikan lele. Perbandingan yang digunakan adalah adalah sebagai berikut: $\mathrm{b} 1=1: 1$ (daging ikan lele : air), b2 = $1: 2$, b3 = $1: 3$, b4 = 1: 4, b5 anak, kegagalan reproduksi serta gangguan ikan lele.Tahapan yang paling penting dalam pembuatan minuman jeli ikan lele adalah pembentukan gel. Pembentukan gel adalah suatu fenomena penggabungan atau pengikatan silang rantai-rantai polimer sehingga terbentuk suatu jala tiga dimensi bersambungan. Selanjutnya jala ini menangkap atau mengimobilisasikan air di dalamnya dan membentuk struktur yang kuat dan kaku (Fardiaz, 1989).

\section{Metodologi Penelitian}

aquadest, bahan analisis kadar abu dengan metode gravimetri : $\mathrm{HCl}$ pekat dan aquadest, seperangkat bahan analisis protein dengan metode kjeldahl : tablet katalis, batu didih, $\mathrm{H}_{2} \mathrm{SO}_{4}$ pekat, $\mathrm{H}_{2} \mathrm{O}_{2} 30 \%$, $\mathrm{H}_{3} \mathrm{BO}_{4}$, indikator methyl red, dan $\mathrm{HCl} 0,2 \mathrm{~N}$, serta alcohol $70 \%$.

Alat-alat yang digunakan dalam proses pembuatan minuman jeli ikan lele antara lain pisau, talenan, wadah plastik, timbangan, blemder, saringan, panci, alat pengaduk, kompor, thermometer dan botol minuman. Sedangkan alat yang digunakan untuk analisis kimia adalah neraca analitik, kertas timbang, oven, cawan alumunium, penjepit cawan, desikator, cawan porsele,

$=1: 5$. Selanjutnya sari daging ikan lele yang didapatkan dari kelima perbandingan tersebut diuji kadar proteinnya dengan metode Kjeldahl (AOAC, 1995) dan dibuat menjadi minuman jeli ikan lele untuk selanjutnya diuji organoleptik. Uji hedonik dilakukan terhadap warna, aroma, rasa, tekstur dan kenampakan.

\section{Rancangan Perlakuan}

Rancang perlakuan terdiri dari satu faktor yaitu penambahan konsentrasi jelly powder yang terdiri dari 12 taraf: $\mathrm{f} 1=0.10 \%, \mathrm{f} 2=0.15 \%, \mathrm{f} 3=$ $0.20 \%, \mathrm{f} 4=0.25 \%, \mathrm{f} 5=0.30 \%, \mathrm{f} 6=0.35 \%, \mathrm{f} 7=$ $0.40 \%, \mathrm{f} 8=0.45 \%, \mathrm{f} 9=0.50 \%, \mathrm{f} 10=0.55 \%, \mathrm{f} 11=$ $0.60 \%, \mathrm{f} 12=0.65 \%$.

Rancangan percobaan yang dilakukan pada penelitian ini adalah Rancangan Acak Kelompok (RAK) dengan faktorial $12 \times 1$ dengan 2 kali pengulangan.

Berdasarkan rancangan percobaan diatas, maka dapat dibuat analisis variansi (ANAVA) untuk mendapatkan kesimpulan mengenai pengaruh perlakuan.

\section{Rancangan Respon}

Respon kimia terhadap minuman jeli ikan lele meliputi analisis kadar air dengan metode destilasi dan analisis gula pereduksi dengan metode Luff Schrools.

Respon fisik terhadap minuman jeli ikan lele yangakan digunakan adalah uji viskositas menggunakan viscometer dan uji total padatan terlarut (TSS) dengan menggunakan refraktometer. 
Uji kesukaan (organoleptik) yang dilakukan berdasarkan tingkat kesukaan panelis dengan metode hedonik (Soekarto, 1985), respon yang diuji meliputi warna, aroma,rasa, tesktur dan kenampakan. Panelis yang digunakan untuk menguji minuman jeli ikan lele yang dihasilkan adalah 20 panelis dengan kriteria penilaian tertentu seperti dapat dilihat pada tabel berikut, dan hasil penelitian dikumpulkan dan dimasukan kedalam formulir pengisian, selanjutnya data tersebut diolah secara statistik.

Tabel 1. Kriteria Penilaian Panelis dalam Uji Hedonik

\begin{tabular}{|c|c|}
\hline Skala Hedonik & Nilai Numerik \\
\hline Sangat tidak suka & 1 \\
Tidak suka & 2 \\
Agak tidak suka & 3 \\
Agak suka & 4 \\
Suka & 5 \\
Sangat suka & 6 \\
\hline
\end{tabular}

Penghilangan Bau Amis

Ikan mengandung trimetilamin (TMA) yang dapat menyebabkan berbau amis (fishy). Trimetil amin dihasilkan oleh senyawa lipoprotein yang diuraikan terlebih dahulu menjadi kolin, kemudian diuraikan lebih lanjut menjadi trimetil amin oksida (TMAO). Trimetil amin oksida akan diubah oleh enzim-enzim yang berasal pada proses kimiawi yang menyebabkan bau menjadi amis (Anggraeni, 2011).

Berdasarkan hasil uji hedonik pada minuman jeli ikan lele dengan lima parameter (warna, aroma, rasa, tekstur, dan kenampakan) dipilih perlakuan a5 (20\%) untuk selanjutnya digunakan pada penelitian pendahuluan tahap kedua dan penelitian utama. Hal ini karena perlakuan a5 $(20 \%)$ memberikan pengaruh nyata terhadap parameter aroma minuman jeli ikan lele, dimana tujuan utama penelitian pendahuluan ini adalah untuk menghilangkan bau amis dari daging ikan lele. Semakin besar konsentrasi perasan air jeruk yang digunakan, semakin berkurang bau amis ikan,

\section{Penelitian Utama \\ Kadar Air}

Hasil uji kadar air dengan menggunakan metode destilasi pada minuman jeli ikan lele dengan dua belas taraf konsentrasi jelly powder dapat dilihat pada Tabel 8 .

Tabel 2. Pengaruh Konsentrasi Jelly powder Terhadap Kadar Air Minuman Jeli Ikan Lele

\begin{tabular}{|l|c|c|}
\hline \multicolumn{1}{|c|}{ Perlakuan } & $\begin{array}{c}\text { Rata-rata } \\
\text { Kadar Air }(\%)\end{array}$ & Taraf Nyata \\
\hline f1 $(0.10 \%)$ & 85.83 & $\mathrm{a}$ \\
\hline f2 $(0.15 \%)$ & 85.58 & $\mathrm{ab}$ \\
\hline f3 $(0.20 \%)$ & 85.45 & $\mathrm{abc}$ \\
\hline
\end{tabular}

Respon Uji Produk Terpilih

Produk terpilih berdasarkan respon kimia, respon fisik dan respon organoleptik selanjutnya dilakukan pengujian proksimat. Uji proksimat yang dilakukan, yaitu kadarprotein dengan metode Kjeldahl dan kadarserat kasar dengan metode Gravimetri.

\section{Hasil dan Pembahasan}

Penentuan Perbandigan Daging Ikan Lele dan Air Berdasarkan hasil uji kadar protein pada sari daging ikan lele dengan lima taraf perbandingan (daging ikan lele : air) dan hasil uji hedonik dengan lima parameter (warna, aroma, rasa, tekstur, dan kenampakan) diatas dapat disimpulkan bahwa perbandingan daging ikan lele dan air yang digunakan untuk penelitian utama adalah perlakuan b3 (1:3). Hal ini karena berdasarkan rata-rata tertinggi pada parameter warna, aroma dan tekstur serta kadar protein sari daging ikan lele dengan perlakuan b3 (1:3) masih cukup tinggi $(6.15 \%)$.

\begin{tabular}{|l|l|l|}
\hline f4 $(0.25 \%)$ & 84.18 & c \\
\hline f5 $(0.30 \%)$ & 83.15 & d \\
\hline f6 $(0.35 \%$ & 80.69 & e \\
\hline f7 $(0.40 \%)$ & 80.15 & f \\
\hline f8 $(0.45 \%)$ & 78.60 & g \\
\hline f9 $(0.50 \%)$ & 77.50 & h \\
\hline f10 $(0.55 \%)$ & 75.37 & i \\
\hline f11 $(0.60 \%)$ & 74.37 & j \\
\hline f12 $(0.65 \%)$ & 73.48 & k \\
\hline
\end{tabular}

Keterangan: Huruf dibaca vertikal. Nilai yang ditandai huruf yang sama menunjukkan tidak berbeda nyata di taraf 5 pada uji lanjut Duncan.

Tabel 8 menunjukkan bahwa pada minuman jeli ikan lele dengan 12 taraf konsentrasi jelly powder berpengaruh nyata terhadap respon kadar air. Dimana f1 $(0.10 \%)$ sampai f3 $(0.20 \%)$ menunjukkan tidak berbeda nyata, f3 $(0.20 \%)$ dan f4 $(0.25 \%)$ tidak menunjukkan berbeda nyata, namun dari perlakuan $\mathrm{f} 4$ sampai dengan perlakuan f12 menunjukkan berbeda nyata. Hal ini dikarenakan perbedaan konsentrasi jelly powder yang digunakan hanya sedikit, yaitu $0.05 \%$ sehingga panelis sulit membedakan minuman jeli pada f1 sampai f4. Minuman jeli ikan lele dengan perlakuan f1 sampai dengan f4 memiliki bentuk yang hampir sama dimana belum terjadi pembentukan gel yang signifikan. Berdasarkan nilai rerata kadar air minuman jeli ikan lele dari perlakuan f1 sampai dengan f12 menunjukkan semakin banyak konsentrasi jelly powder yang digunakan maka semakin turun kadar airnya.

Pembentukan gel adalah suatu fenomena penggabungan atau pengikatan silang rantai-rantai polimer sehingga terbentuk suatu jala tiga dimensi bersambungan. Selanjutnya jala ini menangkap dan mengimobilisasikan air di didalamnya dan membentuk struktur yang kat dan kaku (Fardiaz, 
1989). Rantai-rantai polimer tersebut berasal dari kandungan karbohidrat pada jelly powder dan polimer protein pada sari daging ikan lele. Komposisi jelly powderyang digunakan dalam penelitian ini adalah karagenan dan tepung konyaku. Karagenan merupakan salah satu jenis polisakarida yang tidak dapat dicerna, diektraksi dari algae merah (Rhodophy-ceae) dan dapat meningkatkan viskositas (Muchtadi, 2011). Hal ini menunujukkan semakin banyak jelly powder yang ditambahkan maka semakin banyak air yang ditangkap dan diimobilasasi membentuk struktur yang kuat dan kaku atau disebut gel sehingga kadar air minuman jeli ikan lele semakin rendah.

Gula Pereduksi

Pembuatan minuman jeli ikan lele menggunakan gula sebagai salah satu bahan padat yang ditambahkan. Oleh karena itu perlu dianalisis kadar gula pereduksinya. Hasil analisis kadar gula pereduksi minuman jeli ikan lele dengan dua belas taraf konsentrasi jelly powder dapat dilihat pada Tabel 9.

Tabel 9 menunjukkan bahwa pada minuman jeli ikan lele dengan 12 taraf konsentrasi jelly powder tidak berpengaruh nyata terhadap respon kadar gula pereduksi. Dimana f1 $(0.10 \%)$ sampai f12 $(0.65 \%)$ menunjukkan tidak berbeda nyata. Berdasarkan nilai rerata kadar gula reduksi minuman jeli ikan lele dari perlakuan f1 sampai dengan f12 menunjukkan semakin banyak konsentrasi jelly powder yang digunakan maka semakin turun kadar gula reduksinya.

Menurut Winarno (2007), proses inversi sukrosa terjadi pada suasana asam, dimana semakin tinggi suhu pemanasan maka semakin banyak presentase gula invert yang terbentuk. Sari daging ikan lele cenderung bersifat asam dan jelly powder cenderung bersifat basa, sehingga semakin tinggi konsentrasi jelly powder maka semakin basa $\mathrm{pH}$ minuman jeli ikan lele.Oleh karena itu kadar gula pereduksi minuman jeli ikan lele dari perlakuan f1 sampai f12 semakin rendah.

Tabel 3. Pengaruh Konsentrasi Jelly powder Terhadap Kadar Gula Pereduksi Minuman Jeli Ikan Lele

\begin{tabular}{|l|c|c|}
\hline \multicolumn{1}{|c|}{ Perlakuan } & $\begin{array}{c}\text { Rata-rata } \\
\text { Kadar Gula } \\
\text { Pereduksi }(\%)\end{array}$ & Taraf Nyata \\
\hline f1 $(0.10 \%)$ & 1.395 & $\mathrm{a}$ \\
\hline f2 $(0.15 \%)$ & 1.310 & $\mathrm{a}$ \\
\hline f3 $(0.20 \%)$ & 1.280 & $\mathrm{a}$ \\
\hline f4 $(0.25 \%)$ & 1.275 & $\mathrm{a}$ \\
\hline f5 $(0.30 \%)$ & 1.265 & $\mathrm{a}$ \\
\hline f6 $(0.35 \%$ & 1.220 & $\mathrm{a}$ \\
\hline f7 $(0.40 \%)$ & 1.175 & $\mathrm{a}$ \\
\hline f8 $(0.45 \%)$ & 1.090 & $\mathrm{a}$ \\
\hline f9 $(0.50 \%)$ & 1.080 & $\mathrm{a}$ \\
\hline f10 $(0.55 \%)$ & 1.050 & $\mathrm{a}$ \\
\hline f11 $(0.60 \%)$ & 1.035 & $\mathrm{a}$ \\
\hline f12 $(0.65 \%)$ & 1.020 & $\mathrm{a}$ \\
\hline
\end{tabular}

Keterangan: Huruf dibaca vertikal. Nilai yang ditandai huruf yang sama menunjukkan

tidak berbeda nyata di taraf 5\% pada uji lanjut Duncan.

\section{Viskositas}

Hasil uji viskositas dengan menggunakan alat viskotester pada minuman jeli ikan lele dengan dua belas taraf konsentrasi jelly powder dapat dilihat pada Tabel 10 .

Tabel 4. Pengaruh Konsentrasi Jelly powder Terhadap Viskositas

Minuman Jeli Ikan Lele

\begin{tabular}{|l|c|c|}
\hline \multicolumn{1}{|c|}{ Perlakuan } & $\begin{array}{c}\text { Rata-rata } \\
\text { Viskositas } \\
(\text { dPas })\end{array}$ & Taraf Nyata \\
\hline f1 $(0.10 \%)$ & 0.10 & a \\
\hline f2 $(0.15 \%)$ & 0.18 & b \\
\hline f3 $(0.20 \%)$ & 0.33 & a \\
\hline f4 $(0.25 \%)$ & 0.40 & b \\
\hline f5 $(0.30 \%)$ & 0.65 & c \\
\hline f6 $(0.35 \%$ & 1.20 & d \\
\hline f7 $(0.40 \%)$ & 1.53 & e \\
\hline f8 $(0.45 \%)$ & 1.80 & h \\
\hline f9 $(0.50 \%)$ & 2.00 & f \\
\hline f10 $(0.55 \%)$ & 2.50 & g \\
\hline f11 $(0.60 \%)$ & 3.10 & i \\
\hline f12 $(0.65 \%)$ & 3.40 & j \\
\hline
\end{tabular}

Keterangan: Huruf dibaca vertikal. Nilai yang ditandai huruf yang sama menunjukkan tidak berbeda nyata di taraf 5\% pada uji lanjut Duncan.

Tabel 10 menunjukkan bahwa pada minuman jeli ikan lele dengan 12 taraf konsentrasi jelly powderberpengaruh nyata terhadap respon viskositas. Dimana f1 $(0.10 \%)$ dan f3 $(0.20 \%)$ menunjukkan tidak berbeda nyata, f2 $(0.20 \%)$ dan f4 $(0.25 \%)$ tidak menunjukkan berbeda nyata, namun dari perlakuan f5 sampai dengan perlakuan f12 menunjukkan berbeda nyata. Hal ini dikarenakan perbedaan konsentrasi jelly powder yang digunakan hanya sedikit, yaitu $0.05 \%$ sehingga panelis sulit membedakan minuman jeli pada f1 sampai f4. Minuman jeli ikan lele dengan perlakuan f1 sampai dengan f4 memiliki bentuk yang hampir sama dimana belum terjadi pembentukan gel yang signifikan. Berdasarkan nilai rerata viskositas minuman jeli ikan lele dari perlakuan f1 sampai dengan f12 menunjukkan semakin banyak konsentrasi jelly powder yang digunakan maka semakin tinggi viskositasnya.

Viskositas adalah tahanan yang timbul oleh adanya gesekan antra molekul-molekul didalam zat cair yang mengalir. Suatu larutan protein dalam air mempunyai viskositas atau kekentalan yang relative lebih besar daripada viskositas air sebagai pelarutnya.Viskositas larutan protein tergantung pada jenis protein, bentuk molekul, konsentrasi serta suhu larutan. Viskositas berbanding lurus dengan konsentrasi tetapi berbanding terbalik 
dengan suhu. Larutan suatu protein yang molekulnya panjang, mempunyai viskositas lebih besar daripada larutan suatu protein yang bebrbentuk bulat (Poedjiadi dan Supriyanti, 2005).

Menurut Blanshard dan Mitchell (1979) viskositas merupakan daya perlawanan untuk mengalir dari sistem yang disebabkan oleh adanya gesekan, makin besar daya perlawanan atau gesekan tersebut maka akan semakin kental atau viskos. Karagenan akan mengikat air dalam jumlah besar, karena semakin banyak air yang terikat dan terperangkap sehingga larutan bersifat lebih kental (Wicaksono dkk, 2015). Karagenan merupakan salah satu komposisiutama yang terdapat dalam jelly powder yang digunakan dalam pembuatan minuman jeli ikan lele.

Berdasarkan penjelasan diatas maka dapat diketahui bahwa kandungan protein dalam sari daging ikan lele dan konsentrasi jelly powder yang digunakan untuk membuat minuman jeli ikan lele mempengaruhi viskositasnya. Dimana semakin tinggi konsentrasi jelly powder yang ditambahkan maka semakin tinggi viskositas minuman jeli ikan lele tersebut.

Total Padatan Terlarut (TSS)

Hasil uji kadar total padatan terlarut (TSS) pada minuman jeli ikan lele denganda belas taraf konsentrasi jelly powder dapat dilhat pada Tabel 11.

Tabel 5. Pengaruh Konsentrasi Jelly powder Terhadap Total Padatan Terlarut Minuman Jeli Ikan Lele

\begin{tabular}{|l|c|c|}
\hline Perlakuan & $\begin{array}{c}\text { Rata-rata Total } \\
\text { Padatan } \\
\text { Terlarut } \\
\left({ }^{\circ} \text { Brix }\right)\end{array}$ & Taraf Nyata \\
\hline f1 $(0.10 \%)$ & 16.7 & a \\
\hline f2 $(0.15 \%)$ & 17.1 & c \\
\hline f3 $(0.20 \%)$ & 17.5 & b \\
\hline f4 $(0.25 \%)$ & 17.8 & c \\
\hline f5 $(0.30 \%)$ & 18.0 & d \\
\hline f6 $(0.35 \%$ & 18.4 & e \\
\hline f7 $(0.40 \%)$ & 18.7 & f \\
\hline f8 $(0.45 \%)$ & 19.0 & h \\
\hline f9 $(0.50 \%)$ & 19.2 & f \\
\hline f10 $(0.55 \%)$ & 19.5 & g \\
\hline f11 $(0.60 \%)$ & 19.9 & i \\
\hline f12 $(0.65 \%)$ & 20.1 & i \\
\hline
\end{tabular}

Keterangan: Huruf dibaca vertikal. Nilai yang ditandai huruf yang sama menunjukkan tidak berbeda nyata di taraf 5\% pada uji lanjut Duncan.

Tabel 11 menunjukkan bahwa pada minuman jeli ikan lele dengan 12 taraf konsentrasi jelly powderberpengaruh nyata terhadap respon total padatan terlarut (TSS). Dimana f2 $(0.15 \%)$ dan $\mathrm{f} 4(0.25 \%)$ menunjukkan tidak berbeda nyata, namun kedua perlakuan tersebut menunjukkan berbeda nyata dan perlakuan lainnya. Hal ini dikarenakan perbedaan konsentrasi jelly powder yang digunakan hanya sedikit, yaitu $0.05 \%$ sehingga panelis sulit membedakan minuman jeli pada f1 sampai f4. Minuman jeli ikan lele dengan perlakuan f1 sampai dengan f4 memiliki bentuk yang hampir sama dimana belum terjadi pembentukan gel yang signifikan. Berdasarkan nilai rerata total padatan terlarut minuman jeli ikan lele dari perlakuan f1 sampai dengan f12 menunjukkan semakin banyak konsentrasi jelly powder yang digunakan maka semakin tinggi total padatan terlarutnya.

Menurut (Alistair, 1995) sumber total padatan terlarut "jelly" berasal dari bahan pengental, Na Benzoat, gula yang ditambahkan. Sehingga banyak jelly powder yang ditambahkan maka akan mempengaruhi Total Padatan Terlarut (TSS) pada minuman jeli ikan lele. Oleh karena itu semakin tinggi atau semakin banyak konsnetrasi jelly powder yang digunakan maka semakin tinggi kadar total padatan terlarutnya.

Respon Organoleptik

Warna

Menurut Winarno (2007), penentuan mutu bahan makanan pada umumnya sangat tergantung pada beberapa faktor diantaranya citarasa, warna, tekstur, dan nilai gizi. Sebelum faktor-faktor tersebut dipertimbangkan secara visual faktor warna tampil lebih dahulu dan terkadang sangat menentukan.Selain sebagai faktor yang ikut menentukan mutu, warna juga dapat digunakan sebagai indikator mutu bahan. Warna juga dapat menunjukkan apakah suatu pencampuran atau pengolahan sudah dilakukan dengan baik atau benar. Hasil analisis terhadap respon warna minuman jeli ikan lele dengan perlakuan dua belas taraf konsentrasi jelly powder dapat dilihat pada Tabel 12.

Tabel 6. Pengaruh Konsentrasi Jelly powder Terhadap Respon Warna Minuman Jeli Ikan Lele

\begin{tabular}{|l|c|c|}
\hline \multicolumn{1}{|c|}{ Perlakuan } & $\begin{array}{c}\text { Rata-rata } \\
\text { Respon Warna }\end{array}$ & Taraf Nyata \\
\hline f1 $(0.10 \%)$ & 2.85 & $\mathrm{a}$ \\
\hline $\mathrm{f} 2(0.15 \%)$ & 3.00 & $\mathrm{ab}$ \\
\hline $\mathrm{f} 3(0.20 \%)$ & 3.08 & $\mathrm{a}$ \\
\hline $\mathrm{f} 4(0.25 \%)$ & 3.25 & $\mathrm{abc}$ \\
\hline $\mathrm{f5}(0.30 \%)$ & 3.40 & $\mathrm{abcd}$ \\
\hline $\mathrm{f6}(0.35 \%$ & 3.33 & bcde \\
\hline f7 $(0.40 \%)$ & 3.53 & bcde \\
\hline f8 $(0.45 \%)$ & 3.90 & ef \\
\hline f9 $(0.50 \%)$ & 4.33 & $\mathrm{f}$ \\
\hline f10 $(0.55 \%)$ & 4.08 & def \\
\hline f11 $(0.60 \%)$ & 3.85 & cdef \\
\hline f12 $(0.65 \%)$ & 3.65 & cdef \\
\hline
\end{tabular}

Keterangan: Huruf dibaca vertikal. Nilai yang ditandai huruf yang sama menunjukkan tidak berbeda nyata di taraf 5\% pada uji lanjut Duncan.

Tabel 12 menunjukkan bahwa pada minuman jeli ikan lele dengan 12 taraf konsentrasi jelly powderberpengaruh nyata terhadap respon 
warna.Dimana terjadi kecenderungan tidak berbeda nyata pada setiap 5-6 perlakuan berurutan, misalnya pada $\mathrm{f} 1$ sampai dengan f5 dan f8 sampai dengan f12. Hal ini terjadi karena perbedaan konsentrasi jelly powder yang digunakan hanya sedikit, yaitu $0.05 \%$ sehingga panelis sulit membedakan minuman jeli ikan lele tersebut.Berdasarkan nilai rerata respon warna minuman jeli ikan lele dari perlakuan f1 sampai dengan f9 menunjukkan semakin banyak konsentrasi jelly powder yang digunakan maka semakin tinggi nilai respon kesukaan panelis, dimana f9 memiliki nilai rerata tertinggi sebesar 4.33. Akan tetapi selanjutnya dari f9 sampai dengan 12 terjadi penurunan nilai respon panelis karena warna minuman jeli ikan lele yang dihasilkan cenderung lebih gelap.

Warna minuman jeli ikan leleadalah putih kecoklatan. Warna ini dipengaruhi oleh bahanbahan yang digunakan, yaitu sari daging ikan lele, gula dan jelly powder. Menurut Muchtadi dan Sugiyono (2013), warna bahan pangan dapat disebabkan oleh beberapa sumber, dan salah satu yang terpenting adalah pigmen yang ada dalam tanaman atau hewan. Akan tetapi tidak semua warna disebabkan oleh adanya pigmen dari tanaman dan hewan. Penyebab kedua dari timbulnya warna adalah pengaruh panas terhadap gula yang disebut karamelisasi. Penyebab ketiga dari warna disebabkan oleh reaksi kimia gula dan asam amino dari protein yang dikenal sebagai reaksi pencoklatan (browning) atau reaksi Maillard. Pada keadaan ini gugusan amino dari protein bereaksi dengan gugusan aldehida atau keton dari gula pereduksi yang menghasilkan warna coklat.

Aroma

Aroma merupakan rangsangan yang ditimbulkan oleh bahan yang dicium, terutama yang dirasakan oleh indera pembau (Ashadi, 2014). Pada minuman jeli ikan lele yang paling dikhawatirkan adalah aroma bau amis ikan lele yang masih tercium sehingga menimbulkan kesan yang tidak disukai oleh panelis. Hasil analisis terhadap respon aroma minuman jeli ikan lele dengan perlakuan dua belas taraf konsentrasi jelly powder dapat dilihat pada Tabel 13.

Tabel 13 menunjukkan bahwa pada minuman jeli ikan lele dengan 12 taraf konsentrasi jelly powder tidak berpengaruh nyata terhadap respon aroma.Berdasarkan nilai rerata nilai respon kesukaan panelis terhadap minuman jeli ikan lele dari perlakuan f1 sampai dengan f12 menunjukkan semakin banyak konsentrasi jelly powder yang digunakan maka semakin tinggi nilai respon kesukaan panelis. Aroma dalam suatu sistem pangan tidak hanya ditentukan oleh satukomponen saja tetapi oleh beberapa komponen tertentu serta perbandinganjumlah komponen bahan (Susanti 1993, diacu dalam Karina, 2008).Zat organic sangat sensitive terhadap udara, panas dan terhadap interaksinya satu sama lain. Citarasa dan aroma dari kopi, susu, daging dan sebagian besar bahan pangan lainnya biasanya mengalami perubahan yang secara konstan berkurang selama penanganan, pengolahan dan penyimpanan (Muchtadi dan Sugiyono, 2013). Oleh karena itu semakin tinggi konsentrasi jelly powder yang ditambahkan, maka aroma bau amissari daging ikan lele yang dihasilkan setelah proses pengolahan semakin tertutupi. Selain itu aroma amis ikan lele yang berasal dari senyawa amina tersier (trimetilamina) sudah hilang bereaksi dengan asam sitrat dari air perasan jeruk lemon pada treatment perendaman daging ikan lele sebelum digunakan untuk membuat sari daging ikan lele.

Tabel 7. Pengaruh Konsentrasi Jelly powder Terhadap Respon Aroma Minuman Jeli Ikan Lele

\begin{tabular}{|l|c|c|}
\hline \multicolumn{1}{|c|}{ Perlakuan } & $\begin{array}{c}\text { Rata-rata } \\
\text { Respon Aroma }\end{array}$ & Taraf Nyata \\
\hline f1 $(0.10 \%)$ & 2.58 & $\mathrm{a}$ \\
\hline f2 $(0.15 \%)$ & 2.60 & $\mathrm{a}$ \\
\hline f3 $(0.20 \%)$ & 2.60 & $\mathrm{a}$ \\
\hline f4 $(0.25 \%)$ & 2.65 & $\mathrm{a}$ \\
\hline f5 $(0.30 \%)$ & 2.68 & $\mathrm{a}$ \\
\hline f6 $(0.35 \%$ & 2.75 & $\mathrm{a}$ \\
\hline f7 $(0.40 \%)$ & 2.80 & $\mathrm{a}$ \\
\hline f8 $(0.45 \%)$ & 2.85 & $\mathrm{a}$ \\
\hline f9 $(0.50 \%)$ & 2.88 & $\mathrm{a}$ \\
\hline f10 $(0.55 \%)$ & 3.03 & $\mathrm{a}$ \\
\hline f11 $(0.60 \%)$ & 3.05 & $\mathrm{a}$ \\
\hline f12 $(0.65 \%)$ & 3.18 & $\mathrm{a}$ \\
\hline
\end{tabular}

Keterangan: Huruf dibaca vertikal. Nilai yang ditandai huruf yang sama menunjukkan tidak berbeda nyata di taraf 5\% pada uji lanjut Duncan.

Rasa

Tabel 8. Pengaruh Konsentrasi Jelly powder Terhadap Respon Rasa Minuman Jeli Ikan Lele

\begin{tabular}{|l|c|c|}
\hline \multicolumn{1}{|c|}{ Perlakuan } & $\begin{array}{c}\text { Rata-rata } \\
\text { Respon Rasa }\end{array}$ & Taraf Nyata \\
\hline f1 $(0.10 \%)$ & 2.68 & $\mathrm{ab}$ \\
\hline f2 $(0.15 \%)$ & 2.65 & $\mathrm{a}$ \\
\hline f3 $(0.20 \%)$ & 2.63 & $\mathrm{ab}$ \\
\hline f4 $(0.25 \%)$ & 2.83 & $\mathrm{abcd}$ \\
\hline f5 $(0.30 \%)$ & 3.00 & $\mathrm{abcd}$ \\
\hline f6 $(0.35 \%)$ & 3.30 & $\mathrm{~d}$ \\
\hline f7 $(0.40 \%)$ & 3.38 & $\mathrm{~d}$ \\
\hline f8 $(0.45 \%)$ & 3.30 & $\mathrm{~cd}$ \\
\hline f9 $(0.50 \%)$ & 3.00 & $\mathrm{abcd}$ \\
\hline f10 $(0.55 \%)$ & 2.93 & $\mathrm{abcd}$ \\
\hline f11 $(0.60 \%)$ & 3.03 & $\mathrm{abcd}$ \\
\hline f12 $(0.65 \%)$ & 3.08 & $\mathrm{bcd}$ \\
\hline
\end{tabular}

Keterangan: Huruf dibaca vertikal. Nilai yang ditandai huruf yang sama menunjukkan tidak berbeda nyata di taraf 5\% pada uji lanjut Duncan.

Rasa merupakan salah satu faktor penerimaan konsumen terhadap makanan. Rasa 
suatu bahan pangan dipengaruhi oleh beberapa faktor senyawa kimia, suhu, konsistensi, dan interaksi dengan komponen rasa yang lain (Winarno 2008). Hasil analisis rasa dari perlakuan dua belas taraf konsentrasi jelly powder dapat dilihat pada Tabel 14 .

Tabel 14 menunjukkan bahwa pada minuman jeli ikan lele dengan 12 taraf konsentrasi jelly powderberpengaruh nyata terhadap respon rasa. Dimana terjadi kecenderungan tidak berbeda nyata pada setiap 5-6 perlakuan berurutan, misalnya pada f1 $(0.10 \%)$ sampai dengan f5 $(0.30 \%)$. Hal ini terjadi karena perbedaan konsentrasi jelly powder yang digunakan hanya sedikit, yaitu $0.05 \%$ sehingga panelis sulit membedakan minuman jeli ikan lele tersebut. Berdasarkan nilai rerata respon rasa minuman jeli ikan lele dari perlakuan f1 $(0.10 \%)$ sampai dengan f3 $(0.20 \%)$ menunjukkan penurunan nilai, kemudian dari f4 $(0.25 \%)$ sampai f7 $(0.40 \%)$ terjadi peningkatan, namun dari f8 $(0.45 \%)$ sampai dengan 112 kembali menunjukkan penurunan. Nilai respon kesukaan panelis yang fluktuatif disebabkan rasa minuman jeli ikan lele yang sama karena konsentrasi gula yang ditambahkan pada setiap formulasitidak berbeda, yaitu $15 \%$ sehingga rasa minuman jeli ikan lele sulit untuk dibedakan satu sama lain.

Rasa minuman jeli ikan lele berasal dari sari daging ikan lele dan gula. Gula digunakan sebagai bahan pemanis. Tujuan penambahan bahan pemanis adalah untuk memperbaiki flavor (rasa dan bau) bahan makanan sehingga asa manis yang timbul dapat meningkatakan kelezatan. Sukrosa merupakan pemanis yang paling banyak digunakan arena flavornya leih dapat memberikan kenikmatan manis pada manusia sehingga dianggap sebagai bahan pemanis baku (Winarno dan Rahayu, 1994 dalam Yuianti, 2008).

Tekstur

Tabel 9. Pengaruh Konsentrasi Jelly powder Terhadap Respon Tekstur Minuman Jeli Ikan Lele

\begin{tabular}{|l|c|c|}
\hline \multicolumn{1}{|c|}{ Perlakuan } & $\begin{array}{c}\text { Rata-rata } \\
\text { Respon } \\
\text { Tekstur }\end{array}$ & Taraf Nyata \\
\hline f1 $(0.10 \%)$ & 3.25 & bc \\
\hline f2 $(0.15 \%)$ & 3.53 & cd \\
\hline f3 $(0.20 \%)$ & 3.78 & cde \\
\hline f4 $(0.25 \%)$ & 3.80 & cde \\
\hline f5 $(0.30 \%)$ & 4.00 & de \\
\hline f6 $(0.35 \%)$ & 4.35 & ef \\
\hline f7 $(0.40 \%)$ & 4.75 & f \\
\hline f8 $(0.45 \%)$ & 4.13 & def \\
\hline f9 $(0.50 \%)$ & 3.23 & bc \\
\hline f10 $(0.55 \%)$ & 2.85 & ab \\
\hline f11 $(0.60 \%)$ & 2.70 & ab \\
\hline f12 $(0.65 \%)$ & 3.63 & a \\
\hline Keteran & Huf &
\end{tabular}

Keterangan: Huruf dibaca vertikal. Nilai yang ditandai huruf yang sama menunjukkan tidak berbeda nyata di taraf 5\% pada uji lanjut Duncan.
Tabel 15 menunjukkan bahwa pada minuman jeli ikan lele dengan 12 taraf konsentrasi jelly powderberpengaruh nyata terhadap respon tekstur.Dimana terjadi kecenderungan tidak berbeda nyata pada setiap 3-4 perlakuan berurutan, misalnya pada f10 (0.55\%) sampai dengan $\mathrm{f} 12$ $(0.65 \%)$ yang ditandai dengan huruf yang sama ("a"). Hal ini terjadi karena perbedaan konsentrasi jelly powder yang digunakan hanya sedikit, yaitu $0.05 \%$ sehingga panelis sulit membedakan minuman jeli ikan lele tersebut.Berdasarkan nilai rerata respon tekstur minuman jeli ikan lele dari perlakuan f1 (0.10\%) sampai dengan f7 (0.40\%) terjadi peningkatan nilai respon kesukaan, namun kembali terjadi penurunan dari f7 $(0.40 \%)$ sampai dengan $\mathrm{f} 12(0.65 \%)$. Penurunan nilai respon kesukaan panelis disebabkan semakin banyaknya gel yang terbentuk berbanding lurus dengan semakin banyaknya konsentrasi jelly powder yang digunakan.

Tekstur dalam minuman jeli ditentukan oleh viskositas atau kekentalan minuman jeli. Viskositas yaituderajat kekentalan suatu produk pangan.Viskositas dipengaruhi oleh besarnyakonsentrasi bahan pengental yang ditambahkan dalam hal ini adalah jelly powder.Kekentalan dinyatakan sebagai daya tahan yang diberikan oleh suatucairan terhadap gerakangerakan yang dikenakan pada cairan tersebut (Fardiaz, 1989).

Karagenan merupakan salah satu komposisi utama dari jelly powderyang digunakan untuk membuat minuman jeli. Karagenan merupakan bahan pengental yang berfungsi sebagai bahan pembentuk gel. Oleh karena itu semakin tinggi konsentrasi jelly powder yang ditambahkan maka semakin banyak gel yang terbentuk. Perlakuan f1 sampai $f 7$ minuman jeli ikan lele memiliki tekstur yang masih dapat disedot, akan tetapi pada perlakuan f8 sampai f12 minuman jeli ikan lele sudah memiliki tekstur yang semakin sulit untuk disedot karena semakin banyak gel yang terbentuk. Kenampakan

Kenampakan merupakan penilaian panelis terhadap material yang nampak didalam minuman jeli ikan lele.Material tersebut mungkin dapat berupa serpihan daging ikan lele atau gumpalan gel yang terbentuk.Hasil analisis respon kenampakan minuman jeli ikan lele dapat dilihat pada Tabel 16.

Tabel 16 menunjukkan bahwa pada minuman jeli ikan lele dengan 12 taraf konsentrasi jelly powderberpengaruh nyata terhadap respon kenampakan.Dimana terjadi kecenderungan tidak berbeda nyata pada setiap 2-6 perlakuan berurutan, misalnya pada f1 (0.10\%) sampai dengan f4 $(0.25 \%)$ yang ditandai dengan huruf yang sama ("a"). Hal ini terjadi karena perbedaan konsentrasi jelly powder yang digunakan hanya sedikit, yaitu $0.05 \%$ sehingga panelis sulit membedakan 
minuman jeli ikan lele tersebut.Berdasarkan nilai rerata respon tekstur minuman jeli ikan lele dari perlakuan f1 $(0.10 \%)$ sampai dengan $\mathrm{f} 12(0.65 \%)$ terjadi peningkatan nilai respon kesukaan dimana semakin banyak atau semakin tinggi konsentrasi jelly powder yang digunakan maka semakin tinggi nilai respon kesukaan panelis terhadap kenampakan minuman jeli ikan lele.

Tabel 10. Pengaruh Konsentrasi Jelly powder Terhadap Respon Kenampakan Minuman Jeli Ikan Lele

\begin{tabular}{|l|c|c|}
\hline \multicolumn{1}{|c|}{ Perlakuan } & $\begin{array}{c}\text { Rata-rata } \\
\text { Respon } \\
\text { Kenampakan }\end{array}$ & Taraf Nyata \\
\hline f1 $(0.10 \%)$ & 2.23 & $\mathrm{a}$ \\
\hline f2 $(0.15 \%)$ & 2.43 & $\mathrm{a}$ \\
\hline f3 $(0.20 \%)$ & 2.50 & $\mathrm{a}$ \\
\hline f4 $(0.25 \%)$ & 2.68 & $\mathrm{ab}$ \\
\hline f5 $(0.30 \%)$ & 3.13 & $\mathrm{bc}$ \\
\hline f6 $(0.35 \%$ & 3.35 & $\mathrm{~cd}$ \\
\hline f7 $(0.40 \%)$ & 3.95 & $\mathrm{de}$ \\
\hline f8 $(0.45 \%)$ & 4.00 & $\mathrm{de}$ \\
\hline f9 $(0.50 \%)$ & 4.00 & $\mathrm{de}$ \\
\hline f10 $(0.55 \%)$ & 4.05 & $\mathrm{e}$ \\
\hline f11 $(0.60 \%)$ & 4.23 & $\mathrm{e}$ \\
\hline f12 $(0.65 \%)$ & 4.33 & $\mathrm{e}$ \\
\hline
\end{tabular}

Keterangan: Huruf dibaca vertikal. Nilai yang ditandai huruf yang sama menunjukkan tidak berbeda nyata di taraf 5\% pada uji lanjut Duncan.

Jelly powder merupakan bahan tambahan pangan yang berfungsi sebagai bahan pembentuk gel. Bahan pembentuk digunakan untuk memperbaiki tekstur makanan, sebagai contoh dilakukan pada pengawetan buah-buahan dan produk sayuran, keju, jam dan jeli (Effendi, 2012). Semakin tinggi konsentrasi jelly powder yang ditambahkan maka semakin banyak gel yang terbentuk sehingga kenampakan minuman jeli ikan lele semakin kompak dan semakin disukai oleh panelis.

Sampel Terpilih

Sampel terpilih pada penelitian utama, ditentukan berdasarkan jumlah rata - rata penilaian berdasarkan analisis kimia, fisika, dan uji organoleptik. Dari dua belas formulasi yang berbeda dipilih salah satu yang terbaik. Dari data yang diperoleh secara statistik maka dapat diambil suatu kesimpulan untuk penentuan produk terpilih dari penelitan pembuatan minuman jeli ikan lele. Data statistik hasil analisis kimia, fisika, dan uji organoleptik untuk minuman jeli ikan lele dengan dua belas formulasi yang berbeda dapat dilihat pada Tabel 40 dan Tabel 41 pada halaman 79-80.

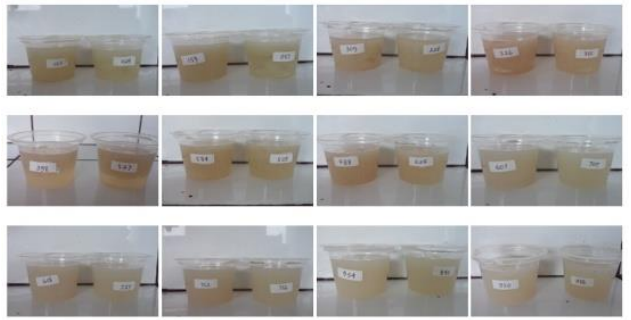

Gambar 1. Minuman Jeli Ikan Lele dengan Dua Belas Formulasi

Berdasarkan data statistik dapat diketahui bahwa perlakuan dua belas formulasi minuman jeli ikan lele menunujukkan perbedaan nyata pada kadar air, viskositas, total padatan terlarut, warna, rasa, tekstur dan kenampakan. Namun perbedaan nyata tersebut tidak signifikan. Hal ini disebabkan perbedaan yang kecil dari setiap formulasi, yaitu hanya selisih 0.05 .

Berdasarkan taraf nyata dari kedua tabel hasil analisis rata - rata respon kimia, fisika, dan uji organoleptik maka didapatkan perlakuan terbaik padapembuatan minuman jeli ikan lele yaitu formula $\mathrm{f} 7$ dengan perlakuan penambahan jelly powder $0.4 \%$. Perlakuan ini dipilih karena diantara perlakuan yang memiliki taraf nyata yang berbeda, perlakuan penambahan jelly powder $0.4 \%$ memiliki nilai respon rasa dan tekstur yang paling disukai oleh panelis dibandingkan dengan perlakuan yang lain.

Sampel terpilih dilakukan analisis kadar protein dengan metode Kjeldahl dan kadar serat kasar dengan metode Gravimetri.

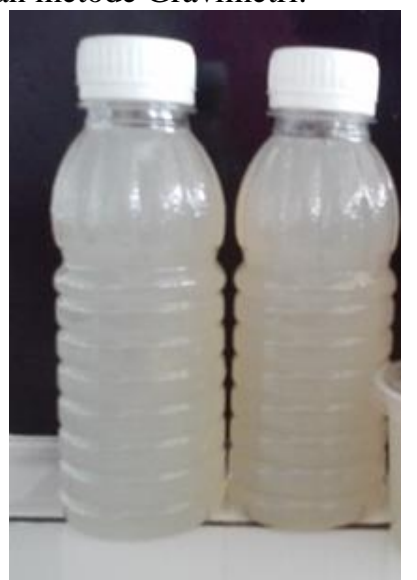

Gambar 2. Sampel Minuman Jeli Ikan Lele Terpilih

Tabel 11. Hasil Analisis Sampel Terpilih

\begin{tabular}{|l|c|c|}
\hline $\begin{array}{c}\text { Formula } \\
\text { Minuman Jeli } \\
\text { Ikan Lele }\end{array}$ & $\begin{array}{c}\text { Kadar Protein } \\
(\%)\end{array}$ & $\begin{array}{c}\text { Kadar Serat } \\
\text { Kasar }(\%)\end{array}$ \\
\hline $\begin{array}{l}\mathrm{f} 7 \\
\text { (penambahan } \\
\text { jelly } \\
\text { powder } 0.4 \%)\end{array}$ & 3.72 & 1.78 \\
\hline
\end{tabular}


Kadar protein pada minuman jeli ikan lele sampel terpilih cenderung turun daripada kadar protein sari daging ikan lele yang digunakan. Sari daging ikan lele yang digunakan memiliki kadar protein sebesar $6.15 \%$ sedangkan setelah dibuat menjadi minuman jeli ikan lele kadar protein turun menjadi $3.72 \%$. Hal ini disebabkan oleh proses pengolahan minuman jeli ikan lele tersebut.

Protein dapat dirusak oleh panas yang berelebihan, bahan kimia, pengadukan yang berelebihan terhadap solusi protein dan adanya penambahan asam dan basa (Warsito, Rindiani dan Nurdyansyah, 2014). Pada proses pengolahan minuman jeli ikan lele, sari daging ikan lele dipanaskan dan diaduk pada suhu $80^{\circ} \mathrm{C}$ selama 5 menit. Hal ini yang menyebabkan turunnya kadar protein. Protein akan mengalami koagulasi apabila dipanaskan pada suhu $50^{\circ} \mathrm{C}$ atau lebih ( Poedjiadi dan Supriyanti, 2005). Koagulasi merupakan proses lanjutan ketika molekul protein yang didenaturasi membentuk suatu massa yang solid. Cairan telur (sol) diubah menjadi pada atau setengah padat (gel) dengan proses air yang keluar dari struktur membentuk spiral-spiral yang membuka dan melekat satu sama lain. Hasil dari proses koagulasi protein biasanya mampu membentuk karakteristik yang diinginkan. Yaitu mengental yang mungkin terjadi pada proses selanjutnya setelah denaturasi dan koagulasi. Kekentalan hasil campuran telur mempengaruhi keinginan untuk menyusut atau menjadi lebih kuat (Vickie, 2008).

Serat adalah bagian dari tanaman yang tidak dapat diserap oleh tubuh. Serat adalah zat non gizi, ada dua jenis serat yaitu serat makanan (dietary fiber) dan serat kasar (crude fiber) (Setiawati dkk, 2015). Serat kasar adalah bagian dari pangan yang tidak dapat terhidrolisis oleh bahan-bahan kimia yang digunakan untuk menentukan kadar serat kasar yaitu asam sulfat (HSO4 1,25\%) dan natrium hidroksida $(\mathrm{NaOH} 1,25 \%)$. Serat kasar merupakan bagian dari karbohidrat dan didefinisikan sebagai fraksi yang tersisa setelah didigesti dengan larutan asam sulfat standar dan sodium hidroksida pada kondisi yang terkontrol. Pengukuran serat kasar dapat dilakukan dengan menghilangkan semua bahan yang larut dalam asam dengan pendidihan dalam asam sulfat (Hunter, 2002). Bahan makanan yang mengandung banyak serat kasar lebih tinggi kecernaannya dibanding bahan makanan yang lebih banyak mengandung bahan ekstrak tanpa nitrogen (Arif, 2006).

Jelly powder yang digunakan dalam pembuatan minuman jeli ikan lele memiliki komposisi campuran dari karagenan dan tepung konyaku. Karagenan merupakan salah jenis serat kasar atau serat yang bersifat tidak tercerna dan dapat membentuk gel dengan air. Karagenan diekstraksi dari algae merah (Rhodophy-ceae) dan dapat meningkatkan viskositas, menurunkan laju pengosongan perut dan waktu transit dalam usus kecil (bersifat hipoglisemik) dan difermentasi dalam usus besar menghasilkan SCFA (Muchtadi, 2011). Jelly powderyang ditambahkan pada sampel terpilih hanya sebesar $0.4 \%$ sehingga minuman jeli ikan lele yang dihasilkan hanya sedikit mengandung serat kasar, yaitu sebesar 1.78.

\section{Daftar Pustaka}

1. Agustin, F. dan Putri, W.D.R. 2014.Pembuatan Jelly Drink Avverhoa blimbi L.(Kajian Proporsi Belimbing Wuluh : Air dan Konsentrasi Karagenan.Universitas Brawijaya. Malang.

2. Anggraeni, M.A. 2011. Pembusukan Ikan Air Tawar Akibat Aeromonas Hydrophila. http://madearyanggreni.blogspot.co.id/2011/06 /pembusukan-ikan-air-tawar-akibat.html [Diunduh: 20 Maret 2017].

3. Alistair, S.M. 1995. Food Polysacharides and their application. Marcel Dekker. Inc. New York.

4. Almatsier, S. 2009. Prinsip Dasar Ilmu Gizi Cetakan ke VII. PT. Gramedia Pustaka Utama. Jakarta.

5. Ashadi, A. Susilo, B. Yulianingsih, R. 2014.Studi Komposisi Sari Jagung Manis dan Karagenan Pada Kualitas Jeli Jagung Manis.Jurnal Biopress Komoditas Tropis Vol.2 No.2. Universitas Brawijaya. Malang.

6. Astawan, M., 2008. Ikan Air Tawar Kaya Protein dan Vitamin. Artikel Departement of Food Science and Technology Bogor Agricultural

University.http://web.ipb.ac.id/ tpg/de/pubde_ tknprcss_ikan.php, Diakses: 2017/03/11.

7. Astuti, S.D. dan Agustia, F.C. 2013.Formulasi dan Karakterisasi Minuman Jeli Fungsional Sumber Serat Pangan dan Vitamin C dari Kappa Karagenan, Konjak Glukomanan, dan Ekstrak Asam Jawa.Universitas Jendral Soedirman.Purwokerto.

8. Atmaka, W., Nurhartadi, E., Karim, M.M 2013. Pengaruh Penggunaan Campuran Karaginan dan Konjak Terhadap Karakteristik Permen Jelly Temulawak (Curcuma Xanthorrhiza Roxb.).Universitas Sebelas Maret. Surakarta.

9. Blanshard, M.W and J.R. Mitchell. 1979. Polysaccarides in Food. Fakahan.London.

10. Buckle,K.A., Edwards, R.A., Fleet, G.H., Wootton M., 1985. Food Science. Penerjemah Hari Purnomo.UI-Press, Jakarta.

11. Cahyadi, W. 2008. Analisis \& Aspek Kesehatan Bahan Tambahan Pangan. Bumi Aksara. Jakarta.

12. Fardiaz, S. 1989. Hidrokoloid .Departemen Pendidikan dan Kebudayaan. Direktorat Jenderal Perguruan Tinggi. Pusat Antar 
Universitas Pangan dan Gizi.Institut Pertanian Bogor. Bogor.

13. Febriyanti, S. dan Yunianta. 2015.Pengaruh Konsentrasi Karagenan dan Rasio Sari Jahe Emprit (Zingiber offinale var. Rubrum) Terhadap Sifat Fisik, Kimia, dan Organoleptik Jelly Drink Jahe.Jurnal Pangan dan Agroindustri Vol.3 No.2.

14. Gaspersz, V. 1995. Teknik Analisis Dalam Penelitian Percobaan. Jilid 1 dan 2. Penerbit Parsito. Bandung.

15. Glicksman. 1983.Food Hydrocoloid. Vol. II. CRC Press.Inc. Florida.

16. Hapsari, A.P.2011. Formulasi dan Karakteristikisasi Minuman Fungsional Fruity Jelly Yogurt Berbasis Kappa Karagenan Sebagai Sumber Serat Pangan. Institut Pertanian Bogor. Bogor.

17. Imeson, A. 2010. Food Stabilisers, Thickness and Gelling Agents.Markono Print Media Pte Ltd. Singapura.

18. Kalsum, U. 2012. Kualitas Organoleptik dan Kecepatan Meleleh Es Krim dengan Penambahan Tepung Konyaku (Amorphopallus onchopillus) Sebagai Bahan Penstabil.Universitas Hasanudin.Makasar.

19. Khoiriyah, N. dan Amalia, L. 2014. Formulasi Cincau Jelly Drink (Premna oblongifolia L Merr) Sebagai Pangan Fungsional Sumber Antioksidan. Jurnal Gizi dan Pangan.Institut Pertanian Bogor. Bogor.

20. Lestari, D.E. 2012. Pengaruh Konsentrasi Hidrokoloid Karagenan Terhadap Mutu Minuman jeli Bunga Rosela (Hibiscus Sabdariffa L.). Universitas Sahid. Jakarta.

21. Machyudin, K. 2008.Panduan Lengkap Agribisnis Lele. Penebar Swadaya. Jakarta.

22. Mariana, I., Widjanarko, S.B. dan Wulan S.N. 2008. Studi Pembuatan Minuman Jeli Wortel dengan Tepung konyaku dan Karagenan sebagai Bahan Pembentuk Gel Ditinjau dari Sifat Fisik, Kimia dan Organoleptik, https://simonbwidjanarko.wordpress.com/2008 /06/11/123/ [Diakses : 16Mei 2017].

23. Marsono, Y. 2007. Prospek Pengembangan Makanan Fungsional. Seminar Nasional "National Food Technology Competition (NFTC) 2007”.Universitas Widya Mandala. Surabaya.

24. Meilgaard, M., Civille, G.V., dan Carr, B.T. 1999.Sensory Evaluation Techniques.CRC Press. Boca Raton.

25. Muchtadi, D. 1989. Protein: Sumber dan Teknologi.Pusat Antar Universitas Pangan dan Gizi.Institut Pertanian Bogor. Bogor.

26. Muchtadi, D. 2011. Karbohidrat Pangan dan Kesehatan Cetakan Kesatu. CV Alfabeta. Bandung.
27. Muchtadi, D., Sugiyono, dan Ayustaningwarno, F. 2015. Ilmu Pengetahuan Bahan Pangan Cetakan Kelima. CV Alfabeta. Bandung.

28. Pamungkas, A. 2014. Pengembangan Produk Minuman Jeli Ekstrak Daun Hantap (Sterculia oblongata $R$. Brown) Sebagai Alternatif Pangan Fungsional. Institut Pertanian Bogor. Bogor.

29. Perwira, T.I. 2010.Pengaruh Konsentrasi Karaginan dan Volume Sari Tomat Terhadap Sifat Fisik, Kimia dan Organoleptik Jelly Drink Tomat.http://eprints.umm.ac.id/3185/ [Diakses : 2017/06/10].

30. Poejiadi, A.1994.Biokimia. UI-Press. Jakarta.

31. Poedjiadi, A. 2005. Dasar-dasar Biokimia Edisi Revisi. UI-Press. Jakarta.

32. Pranajaya, D. 2007. Pendugaan Sisa Umur Simpan Minuman Jelly di Pasaran. Institut Pertanian Bogor. Bogor.

33. Restiana, R.I., Wignyanto, Febrianto, A. 2013.Pembuatan Jelly Drink Filtrat Kulit Pisang Candi (Musa acuminata) (Kajian Penambahan Konsentrasi Karaginan dan Agaragar). Universitas Brawijaya. Malang.

34. Sugiarso, A. dan F.C. Nisa, 2015. Pembuatan Minuman Jeli Murbei (Morus alba L.) dengan Pemanfaatan Tepung Porang (A. Muelleri blume) Sebagai Pensubtitusi Karagenan. Jurnal Pangan dan Agroindustri Vol.3 No.2.

35. Sumardjo, D. 2006. Pengantar Kimia. Buku Kedokteran EGC. Jakarta.

36. Utami, U.T., 2010. Pemanfaatan Kunyit (Curcuma domestica Val) dan Jeruk Nipis (Citrus aurantifolla Swingle) dalam Pembuatan Abon Ikan Lemuru (Sardinella lemuru).Insititut Pertanian Bogor. Bogor.

37. Wicaksono, G.S. dan E. Zubaidah.2015.Pengaruh Karagenan dan Lama Perebusan Daun Sirsak Terhadap Mutu dan Karakteristik Jelly Drink Daun Sirsak.Jurnal Pangan dan Agroindustri Vol.3 No.1.

38. Suryaningrum T.D., Ikasari D., Murniyati. 2012. Aneka Produk Olahan Lele Edisi ke-1 . Penebar Swadaya. Jakarta.

39. Suyanto, S. R. 1986. Budidaya Ikan Lele Edisi ke-1. Penebar Swadaya. Jakarta.

40. Vaclavik, Vickie. A dan Elizabeth W. Cristian. 2008. Essential of Food Science Third Edition. Springer Science and Business Media.

41. Winarno, F.G. dan Rahayu, T.S. 1994.Bahan Tambahan untuk Makanan dan Kontaminan. Pustaka Sinar Harapan. Jakarta.

42. Winarno F.G. dan Kartawidjajaputra F. 2007. Pangan Fungsional dan Minuman Berenergi. M-brio press. Bogor.

43. Winarno F.G. 2008.Kimia Pangan dan Gizi.Bogor : M-Brio Press. Bogor. 
44. Winarti, S. 2010. Makanan Fungsional. Graha Ilmu. Yogyakarta.

45. Wulandari, S., Sayuti, I., Asmaini. 2005. Analisis Mikrobiologi Produk Ikan Kaleng (Sardines) Kemasan dalam Limit Waktu Tertentu (Expire). Jurnal Biogenenesis Vol. 2 (I):30-35, 2005.

46. Yuliani, Marwati, Fahriansyah, M.W.R. 2011. Studi Variasi Konsentrasi Ekstrak Rosela (Hibiscus sabdariffa L.) dan Karagenan Terhadap Mutu Minuman Jeli Rosela. Jurnal Teknologi Pertanian Vol.7 No.1.

47. Yulianti, R. 2008. Pembuatan Minuman Jeli Daun Kelor (Moringa Oleifera Lamk) sebagai Sumber Vitamin C dan $ß$-Karoten. Institut Pertanian Bogor. Bogor. 